\title{
Production and rooting of cordia - Cordia trichotoma (Vell.) Arrab. ex Steud. mini- cuttings collected from ministumps of asexual and seminal origin
}

\author{
Produção e enraizamento de miniestacas de louro-pardo - Cordia trichotoma (Vell.) Arrab. ex \\ Steud. coletadas de minicepas de origem assexuada e seminal
}

\author{
Paula Kielse $^{\mathrm{I}}$ Dilson Antônio Bisognin ${ }^{\mathrm{I}^{*}}$ Kelen Lencina Haygert ${ }^{\mathrm{II}}$ Uilian Stefanello Mello $^{\mathrm{III}}$ \\ Nathalia Pimentel ${ }^{\mathrm{II}}$ Marcelo Artur Raube ${ }^{\mathrm{IV}}$
}

\section{- NOTE -}

\begin{abstract}
This study aimed to evaluate the production of cordia (Cordia trichotoma) ministumps of seminal and asexual origin, as well as the effect of the naphthaleneacetic acid (NAA) on the rooting of mini-cutitings. Seedlings and plantlets from rooted cuttings were pruned to form a clonal mini-hedge. The ministumps were fertirrigated with three concentrations of nutrient solution and they were evaluated for survival and production of minicuttings. The mini-cuttings were or not treated with $1000 \mathrm{mg} \mathrm{L}^{-1}$ of $N A A$ and planted in substrate for rooting. The mini-cuttings were evaluated for the percentages of survival and rooting, and number and total length of roots after 30 days of cultivation. There was no difference in survival and number of mini-cuttings obtained from seminal or asexual ministumps. Mini-cuttings from ministumps of asexual origin showed higher rooting capability. The use of $1000 \mathrm{mg} \mathrm{L}^{-1} \mathrm{NAA}$ did not increase the rooting percentage of cordia mini-cuttings.
\end{abstract}

Key words: clonal mini-hedge, asexual propagation, mini-cutting, plantlet production.

\section{RESUMO}

O objetivo deste trabalho foi avaliar a produtividade de minicepas de louro-pardo (Cordia trichotoma) de origem seminal e assexuada, bem como o efeito do ácido naftaleno acético (ANA) no enraizamento das miniestacas. Mudas de origem seminal $e$ do enraizamento de estacas radiculares foram podadas para formar o minijardim clonal. As minicepas foram fertirrigadas com três concentrações de solução nutritiva e avaliadas quanto à sobrevivência e produtividade de miniestacas. As miniestacas foram ou não tratadas com 1000mg $L^{-1}$ ANA e plantadas em substrato para o enraizamento. As miniestacas foram avaliadas para as porcentagens de sobrevivência e enraizamento e para o número e comprimento total de raízes, aos 30 dias de cultivo. Não houve diferença quanto à sobrevivência e o número de miniestacas obtidas de minicepas de origem seminal ou assexuada. Miniestacas oriundas de minicepas de origem assexuada apresentaram maior capacidade de enraizamento e sobrevivência. A aplicação de $1000 \mathrm{mg}^{-1}$ de ANA não favorece o enraizamento das miniestacas de louro-pardo.

Palavras-chave: minijardim clonal, silvicultura clonal, miniestaquia.

In clonal mini-hedge, the production of ministumps should vary among clones, management techniques, ministump age and vigor, among others factors (DIAS et al., 2012). The nutritional management has also been a determinant factor for the competency of mini-cutting rooting, because well-nourished propagules have high availability of endogenous auxin, amino acids, carbohydrates, and other substances that facilitate differentiation and root formation.

Studies have shown that cordia (Cordia trichotoma), a native tree species of the Boraginaceae family, presents propagules with low-rooting competence, because unsatisfying rhizogenesis responses have been obtained in both mini-cuttings of adult shoots and cuttings (FICK, 2007; HEBERLE et al., 2010). As far as it is know, there are no references on cordia mini-cutting technology, which is the

\footnotetext{
'Departamento de Fitotecnia, Universidade Federal de Santa Maria (UFSM), Av. Roraima 1000, Prédio 77, Camobi, 97105-900, Santa Maria, RS, Brasil. E-mail: dilson.bisognin@ufsm.br. "Corresponding author.

IIPrograma de Pós-graduação em Engenharia Florestal, UFSM, Santa Maria, RS, Brasil.

IIICurso de Agronomia, UFSM, Santa Maria, RS, Brasil.

${ }^{\text {IV }}$ Curso de Engenharia Florestal, UFSM, Santa Maria, RS, Brasil. 
rationality of this study to evaluate the influence of the ministump origin and the different concentrations of nutrient solution on the mini-cutting production and NAA effect on rooting. The clonal mini-hedge was established in polyethylene trays, placed in a greenhouse and fertirrigated as described in BANDINELLI et al. (2013). The nutrient solution was formulated with $100 \%, 75 \%$ and $50 \%$ of the original concentration. The complete nutrient solution have the following macronutrients (in $\mathrm{mmol} \mathrm{L}^{-1}$ ): 6.1 of potassium nitrate, 10.0 of calcium nitrate, 16.8 of magnesium sulphate, 1.4 of ammonium nitrate, 1.4 of potassium mono-phosphate and 1.7 of chelate iron $5 \%$. The micronutrients were added to the complete nutrient solution as a previously prepared blend containing (in mmol L-1): 0.15 of sodium molybdate, 0.89 of boric acid, 1.25 of copper sulphate, 1.23 of manganese sulphate and 0.28 of zinc sulphate.

For clonal mini-hedge formation, oneyear-old seedlings (seminal origin) and plantlets (rooted cuttings) were transplanted to the growing beds of the polyethylene trays. After 10 days of cultivation, they were pruned at $6.0 \mathrm{~cm}$ height to get the ministumps, which provided the sprouts to prepare the mini-cuttings. Sprouts were collected at 30 and 60 days after pruning and the number of minicuttings produced per ministump was recorded. The experiment was a factorial (three nutrient solutions and two ministumps origin) in a complete random design, with four replications of one ministump.

Mini-cuttings of a single bud with $3 \mathrm{~cm}$ of length and one leaf with $25 \%$ of the original area from the first harvest were evaluated for rooting capability. Mini-cuttings were treated or not with $1000 \mathrm{mg} \mathrm{L}^{-1}$ of NAA during 10s and cultivated in a mixture of commercial substrate of pine bark, coarse sand and carbonized rice husks $(1: 1: 1 \mathrm{v} / \mathrm{v})$. The survival and rooting rate, number and total length of roots were evaluated at 30 days. The experiment was a factorial (two ministumps origin and two NAA doses) in a complete random design, with three replications of ten mini-cuttings.

Cordia ministumps of both origins (seedlings and plantlets) presented $100 \%$ of survival, from both first and second harvest, suggesting that the management of the clonal mini-hedge was adequate, regardless of the concentration of the nutrient solution. There was no interaction between the ministumps origin nor did the concentration of the nutrient solution and neither the factors affected the production of minicuttings per ministumps (Table 1). Each ministump produced an average of 3.8 mini-cuttings per harvest at 30 day intervals.
Mini-cuttings obtained from ministumps of asexual origin presented higher rooting rate and higher number and length of roots (Table 2). This result was expected, since the ministumps came from rooted cuttings, in other words, the plantlets were originated from genotypes capable of rooting. It was also observed that the application of $1000 \mathrm{mg} \mathrm{L}^{-1}$ of NAA did not increase rooting and mini-cutting survival (Table 2), allowing new researches to be tested with other doses and types of auxin.

It is worth pointing out that the vegetative propagation of cordia must be done with mini-cuttings collected from selected trees, being necessary studies on rejuvenation techniques to rescue these plants. A major advance in vegetative propagation of cordia was the production of plantlets by rooting juvenile radicular minicuttings (KIELSE et al., 2013), which were used to successfully establish a clonal minihedge of the present research. Ministumps of seminal and asexual origin did not differ for mini-cuttings production, regardless of the concentrations of the nutrient solution for fertirrigation. However, in this study it was observed that mini-cuttings of asexual origin presented higher rooting capacity when compared to the mini-cuttings of seminal origin. Irrespective of the future studies, this research is the first rooting report of cordia mini-cuttings and clearly showed that plantlets got from rooted cutting can be used for the formation of clonal mini-hedge and minicuttings can be rooted even without the application of $1000 \mathrm{mg} \mathrm{L}^{-1}$ of NAA.

Table 1 - Number of mini-cuttings per ministump of cordia collected from ministumps of different origins, fertirrigated with three concentrations of nutrient solution and produced at 30 and 60 days after drastic pruning.

\begin{tabular}{|c|c|c|c|}
\hline Treatments & First harvest & Second harvest & Average \\
\hline \multicolumn{4}{|c|}{----------------------------Ministumps origin ${ }^{1}-$} \\
\hline Asexual & 2.1 & 4.9 & $3.5 \mathrm{a}^{3}$ \\
\hline Seminal & 3.4 & 4.8 & $4.1 \mathrm{a}$ \\
\hline \multicolumn{4}{|c|}{-Notution ${ }^{2}$} \\
\hline Original & 3.1 & 5.0 & $4.1 \mathrm{a}$ \\
\hline $75 \%$ of concentration & 2.4 & 4.8 & $3.6 \mathrm{a}$ \\
\hline $50 \%$ of concentration & 2.8 & 4.8 & $3.8 \mathrm{a}$ \\
\hline Average & 2.7 & 4.8 & 3.8 \\
\hline CV $(\%)$ & & & 25.6 \\
\hline
\end{tabular}

${ }^{1}$ Ministumps from one-year-old seedlings (seminal) and plantlets obtained from rooting of root cuttings (asexual).

${ }^{2}$ The original nutrient solution contains $100 \%$ of the mineral concentrations as described in WENDLING et al. (2007).

${ }^{3}$ Values followed by the same letter do no differ by the Tukey test at $5 \%$ probability. 
Table 2 - Rooting and survival responses of cordia mini-cuttings collected from ministumps of asexual and seminal origin and treated or not with naphthalene acetic acid (NAA), after 30 days of cultivation.

\begin{tabular}{|c|c|c|c|c|}
\hline Treatments & Rooting (\%) & Number of roots & Total root length $(\mathrm{cm})$ & Survival (\%) \\
\hline \multicolumn{5}{|l|}{---------------- } \\
\hline Asexual & $38.3 a^{2}$ & $0.71 \mathrm{a}$ & $5.0 \mathrm{a}$ & $51.6 \mathrm{a}$ \\
\hline Seminal & $1.6 \mathrm{~b}$ & $0.01 \mathrm{~b}$ & $0.2 b$ & $5.0 \mathrm{~b}$ \\
\hline 0 & $26.6 \mathrm{a}$ & $0.53 \mathrm{a}$ & $3.1 \mathrm{a}$ & $36.6 \mathrm{a}$ \\
\hline 1000 & $13.3 \mathrm{a}$ & $0.20 \mathrm{a}$ & $2.1 \mathrm{a}$ & $20.0 \mathrm{a}$ \\
\hline Average & 19.9 & 0.36 & 2.6 & 28.3 \\
\hline CV (\%) & 38.3 & 14.67 & 51.5 & 41.7 \\
\hline
\end{tabular}

${ }^{1}$ Mini-cuttings collected from one-year-old ministumps (seminal) and mini-cuttings collected from ministumps obtained from plantlets of root cuttings (asexual).

${ }^{2}$ Values followed by the same letter do no differ by the Tukey test at $5 \%$ probability.

\section{ACKNOWLEDMENTS}

To the Coordenação de Aperfeiçoamento de Pessoal de Nível Superior (CAPES) and the Conselho Nacional de Desenvolvimento Científico e Tecnológico (CNPq) for scholarship grants.

\section{REFERENCES}

BANDINELLI, M.G. et al. Concentração dos sais e da sacarose do meio MS na multiplicação in vitro e na aclimatização de batata. Horticultura Brasileira, v.31, n.2, p.242-247, 2013. Available from: $<$ http://www.scielo.br/scielo.php?script=sci_artt ext\&pid=S0102-05362013000200011 > . Accessed: Jan. 15, 1015. doi: $10.1590 / \mathrm{S} 0102-05362013000200011$

DIAS, P.C. et al. Propagação vegetativa de meios-irmãos de angico-vermelho (Anadenanthera macrocarpa (Benth) Brenan) por miniestaquia. Revista Árvore, v.36, n.3, p.389-399, 2012. Available from: <http:/www.scielo.br/scielo.php?pid=S010067622012000300001\&script=sci_arttext $>$. Accessed: Jan. 15, 2015. doi: 10.1590/S0100-67622012000300001.

FICK, T.A. Estabelecimento in vitro e propagação de Cordia trichotoma (Vell.) Arrabida ex Steudel (louro-pardo). 2007. 63f. Dissertação (Mestre em Engenharia Florestal) - Universidade Federal de Santa Maria, Santa Maria, RS.

KIELSE, P. et al. Propagação vegetativa de Cordia trichotoma (Vell.) Arrab. ex Steudel por estaquia radicular. Revista Árvore, v.37, n.1, p.59-66, 2013. Available from: <http://dx.doi. org/10.1590/S0100-67622013000100007>. Accessed: Jan. 15, 2015. doi: 10.1590/S0100-67622013000100007.

HEBERLE, M. et al. Estaquia de louro-pardo. In: JORNADAS TÉCNICA FORESTALES Y AMBIENTALES, 14., 2010, Missiones. Anais... Missiones: UNaM, 2010. p.1-7. 